\title{
IDENTIFIKASI SPESIES UDANG MANTIS (STOMATOPODA) DI PERAIRAN KOTA BENGKULU
}

\author{
Nopia Santri Situmeang, Dewi Purnama, Dede Hartono \\ Program Studi IImu Kelautan, Fakultas Pertanian, Universitas Bengkulu \\ Email: nopiasukses@gmail.com
}

Received August 2017, Accepted September 2017

\begin{abstract}
ABSTRAK
Udang Mantis merupakan salah satu jenis crustacea yang memiliki kandungan nutrien yang cukup tinggi yaitu protein 43,91\%; lemak 12,35\%; serat kasar 16,01\%. Udang ini hidup diantara susunan terumbu karang yang sangat kompleks. Udang Mantis dapat hidup di air laut maupun air payau. Habitat sebagian besar Udang Mantis adalah pantai dan senang hidup di dasar air terutama pasir berlumpur. Populasi Udang Mantis tersebar di kota Bengkulu tetapi tidak banyak dikonsumsi oleh masyarakat Kota Bengkulu maupun di luar kota Bengkulu karena dagingnya sedikit. Selain itu pengetahuan tentang kandungan dan juga manfaat udang ini belum banyak diketahui oleh masyarakat kota Bengkulu dan juga pemasarannya masih sangat jarang sekali bahkan hampir terbilang tidak ada yang memasarkannya. Dilihat dari segi ekologinya Udang Mantis (Stomatopoda) merupakan makhluk yang memiliki peran penting dalam ekosistem terumbu karang dengan menjaga populasi dan memelihara semua spesies yang ada baik secara langsung maupun tidak langsung. Penelitian ini bertujuan untuk mengidentifikasi spesies Udang Mantis (Stomatopoda) di Kota Bengkulu.adapun lokasi penelitian yaitu di Pantai Zakat, PPI Pondok Besi dan PPI Pulau Baai. Berdasarkan hasil penelitian yang telah dilakukan di 3 Stasiun peneliti menemukan Udang Mantis di Perairan Kota Bengkulu yang kemudian diidentifikasi sampai ke tingkat spesies. Dari 36 sampel yang diidentifikasi hanya ditemukan satu spesies yaitu Harpiosquilla raphidea. Daerah penangkapan Udang Mantis berlokasi di sekitar perairan yang tidak jauh dari pantai.
\end{abstract}

Kata Kunci: Identifikasi, Kota Bengkulu, Udang Mantis

\begin{abstract}
Mantis shrimp is a type of crustacea that has a high nutrient content of 43.91\% protein; Fat 12.35\%; Crude fiber 16.01\%. These shrimp live among in arrengement of a complex coral reefs. Mantis shrimp can live both in sea water and brackish water. Mostly the habitat of Mantis Shrimp
\end{abstract}


Is a beach and happy to live on the water, especially muddy sand. The population of Mantis Shrimp spread in Bengkulu city but not much consumed by people of Bengkulu City and outside Bengkulu city because the little lesh. Moreover, the knowledge of the content of Mantis shrimp and also the benefits of it is not widely known by the people of Bengkulu city and also marketing is still very rarely even be regarded almost no marketing at all.In terms of ecology, Mantis shrimp (Stomatopoda) is a creature that has an important role in coral reef ecosystems by maintaining the population and maintaining all existing species either directly or indirectly. This study aimed to identify the species of Mantis Shrimp (Stomatopoda) in Bengkulu City. The research location is located at Zakat Beach, Pondok Besi fish landing base and Pulau Baai fish landing base. Based on the results of research that has been done in 3 stations, researcher found that Shrimp Mantis in Bengkulu City waters which are then identified up to the species level. From the 36 samples that identified only a species found that was Harpiosquilla raphidea. The Mantis Shrimp catching area is located around the waters not far from the beach.

Keywords: Bengkulu City, Identification, Mantis Shrimp

\section{PENDAHULUAN}

Udang Mantis secara taksonomi termasuk merupakan kelas Malocostraca dengan ordo Stomatopoda. Lebih dari 400 spesies telah dikenali yang masuk kedalam lebih dari 100 genus. Jumlah Familia Stomatopoda yaitu 19 yang digolongkan ke dalam lima super families, yaitu Bathysquilloidea, Squilloidea, Erythrosquilloidea, Lysiosquilloidea dan Gonodactyloidea (Barber and Erdmann, 2000).

Dilihat dari segi ekologinya Udang Mantis (Stomatopoda) merupakan makhluk yang memiliki peran penting dalam ekosistem terumbu karang dengan menjaga populasi dan memelihara semua spesies yang ada baik secara langsung maupun tidak langsung. Perilaku hidup dari Udang Mantis yang menggali lubang pada terumbu karang memberi peluang untuk oksigenisasi sehingga kesehatan terumbu karang akan lebih terjaga. Udang Mantis akan menggali terumbu karang yang kondisinya tidak baik, sehingga dapat disimpulkan peran Udang Mantis dalam ekosistem laut sebagai bioindikator (Barber et al., 2002).

Udang Mantis tersebar hampir di seluruh Indonesia. Halomoan (1999) melaporkan bahwa di perairan Teluk Banten ditemukan Udang Mantis jenis Squillaharpaxde Haan dengan panjang maksimum yang tertangkap adalah $31,9 \mathrm{~cm}$. Azmarina (2007) melaporkan bahwa di perairan Bagan Siapi Api ditemukan Udang Mantis jenis Harpiosquilla raphidea Fabricius; Ahyong dan Moosa (2004) dalam penelitiannya di Kepulauan Anambas, Natuna menemukan 12 spesies ordo Stomatopoda, diantaranya adalah Aerosquilla indica, Carinosquilla carinata, Oratosquilla perpensa, dan Oratosquilla quinquedentata; sedangkan di perairan Sulawesi Utara ditemukan spesies baru Udang Mantis, yaitu 
Lysiosquilloide smapia (Wardiatno et al., 2009), di Pemuteran Bali ditemukan empat spesies yaitu Haptosquilla glyptocerus, Gonodactylus annularis, Gonodactylus viridis dan Chrisuilla hystrix (Pujawan, 2012). Hasil observasi ditemukan Udang Mantis di Kota Bengkulu.

Populasi Udang Mantis tersebar di kota Bengkulu tetapi tidak banyak dikonsumsi oleh masyarakat Kota Bengkulu. Di Muko Muko Udang Mantis hanya dijadikan sebagai tangkapan sampingan oleh nelayan padahal di beberapa negara yaitu Spanyol, Italia, Yunani, dan Maroko dimanfaatkan sebagai hidangan makanan yang mahal harganya (Rainaldi, 2016).

Udang Mantis yang ada di kota Bengkulu belum diketahui jenisnya sehingga perlu dilakukan identifikasi. Pujawan (2012) menyatakan bahwa penelitian yang berkaitan dengan spesies ini di perairan Indonesia sangat sedikit. Banyak jenis hewan laut di Indonesia yang belum diketahui spesies, jalur distribusi dan populasinya, termasuk Udang Mantis yang dikenal baru di Indonesia. Identifikasi spesies dari Udang Mantis di Bengkulu belum dilakukan. Suatu spesies perlu diidentifikasi agar kita mengetahui klasifikasi maupun morfologinya. Disamping itu juga dapat memberikan informasi dan pengetahuan yang berkaitan dengan suatu spesies.

\section{METODOLOGI}

\section{Materi Penelitian}

Sampel Udang Mantis sebanyak 36 ekor dikumpulkan dari Pantai Kualo, PPI Pondok Besi dan PPI Pulau Baii. Penelitian ini telah dilaksanakan pada bulan Mei sampai bulan Juni 2017.

\section{Metode Penelitian}

Pengambilan sampel Udang Mantis menggunakan metode survey yaitu dengan pengumpulan sampel mantis di Pantai Kualo, PPI Pondok Besi dan PPI Pulau Baai yang merupakan tempat pelelangan atau pendaratan ikan oleh nelayan di Kota Bengkulu.

\section{Pengambilan Sampel}

Sampel diambil langsung dari lokasi penelitian yaitu Pantai Kualo, PPI Pondok Besi dan PPI Pulau Baai. Sampel yang diambil dari berbagai kelas ukuran dengan kondisi sempurna atau memiliki bagian tubuh yang masih utuh. Sebagai data tambahan lokasi penangkapan dicatat posisinya dengan menggunakan peta print yang diberikan kepada nelayan. Sampel yang sudah dikumpulkan dibawa ke Laboratorium. Di Laboratorium sampel diidentifikasi jenisnya dengan menggunakan buku kunci identifikasi. 


\section{Analisis Data}

\section{Identifikasi Jenis Udang Mantis}

Identifikasi sampel dilakukan dengan cara mengamati ciri- ciri morfologinya menggunakan buku Biodiversity Stomatopods (Manning,1998) dan Catalog of Mantis Shrimp (Ahyong et al., 2008). Hasil identifikasi dibahas secara deskriptif.

\section{HASIL DAN PEMBAHASAN}

\section{Gambaran Umum Lokasi Penelitian}

Jumlah penduduk Kota Bengkulu \pm 356.253 jiwa Bengkulu merupakan salah satu provinsi dengan luas pantai wilayah laut $387,6 \mathrm{Km}^{2}$ dengan mata pencaharian utama yaitu di perdagangan (BDA, 2012). Salah satunya adalah di sektor perikanan dan kelautan. Tidak heran apabila masyarakat pesisir Bengkulu cenderung memilih nelayan sebagai mata pencaharian (BPS, 2012). Kecenderungan ini bahkan meningkat disebabkan harga ikan maupun udang yang semakin meningkat pula (Septaria, 2013). Wilayah Provinsi Bengkulu yang berbatasan langsung dengan Samudera Hindia menunjukkan besarnya potensi perikanan. Terdapat 2 Pangkalan Pendaratan Ikan (PPI) di Kota Bengkulu yaitu PPI Pondok Besi dan PPI Pulau Baai.

Kota Bengkulu memilki potensi udang yang sangat baik tetapi belum tergarap dengan sempurna oleh nelayan Bengkulu. Udang Mantis sendiri kurang diminati oleh msyarakat karena dagingnya yang sedikit dan baunya yang menyengat (amis).

\section{Jenis Udang Mantis Yang Ditemukan}

Berdasarkan hasil analisis 36 sampel yang diambil dari 3 stasiun penelitian ditemukan satu jenis Udang Mantis, yaitu Harpiosquilla raphidea. Adapun kedudukan taksonomi Harpiosquilla raphidea. Udang Mantis menurut Manning (1969) dan Bliss (1982) adalah sebagai berikut:

Kingdom : Animalia

Filum : Arthropoda

Kelas : Malacostraca

Subkelas : Hoplocarida

Ordo : Stomatopoda

Subordo : Unipeltata

Superfamili : Squilloidea

Famili : Squillidae

Genus : Harpiosquilla

Spesies : Harpiosquilla raphidea

Nama Lokal : Udang Ketak 
Nama lain Udang Mantis adalah udang lipan, udang mentadak, udang eiko, udang ronggeng,dan udang belalang,dalam Bahasa Inggris disebut mantis shrimp atau ada juga yang menyebut dengan praying shrimp. Disebut Udang Mantis karena penampilan dan karakteristiknya mirip dengan belalang sembah (mantis) belalang sembah (mantis). Didaerah Serang, Banten, udang ini biasa disebut dengan udang cakrek atau udang plethok, sedangkan didaerah Indera Giri Hilir, Riau, Udang Mantis disebut dengan nama udang nenek. Di Austalia Udang Mantis terkenal dengan nama“prawn killers"(Gonser, 2003). Morfologi Udang Mantis dapat dilihat pada gambar 1 .

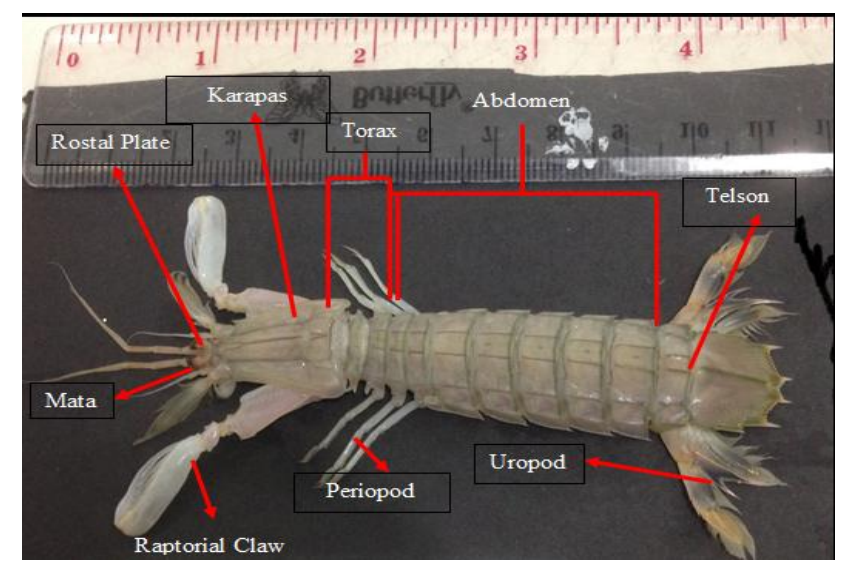

Gambar 1. Morfologi tubuh Udang Mantis (Harpiosquilla raphidea)

Menurut Martin and Davis (2001) genus Harpiosquilla dari famili Squillidae merupakan stopomoda yang terbanyak dan terbesar sedangkan Harpiosquilla raphidea adalah spesies terbesar, yang mencapai total panjang lebih dari $38 \mathrm{~cm}$ (Manning,1969). Hasil penelitian ini juga sama dengan spesies Udang Mantis yang ditemukan di Kuala Tungkal, Jambi (Mashar, 2011), dan Di Bagan Siapi-Api ditemukan (Azmarina, 2007).

Dengan 4 atau lebih intermediate denticles, telson dengan 4 atau lebih jarak yang dekat intermediate denticles yang diatur dalam baris yang teratur. Propodus dari garis raptorial claw cakar berduri pada margin oklusal. Rostal plate dengan dengan lateral marginnyabergelombang membentuk proyeksi apikal yang ramping. Distal uropod exsopod kehitamhitaman. Median carina dari telson tanpa sepasang 'ocelli' hitam.Kejelasan dari exsopod bagian terminal. Kebanyakan telson dengan median carina yang jelas. Submedian teeth yang membantu pergerakan. Uropod protopod dengan dua duri utama (Gambar 2). 
a.

e.

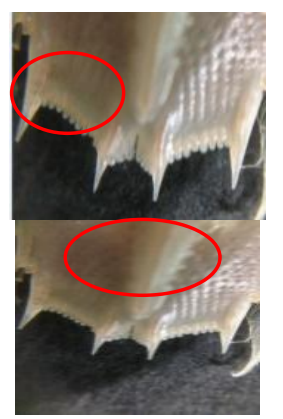

b.

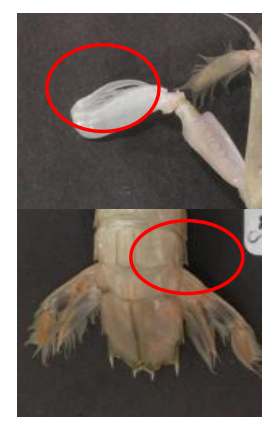

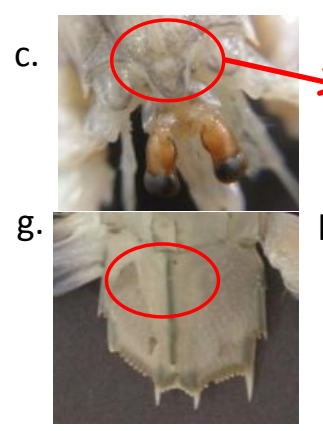

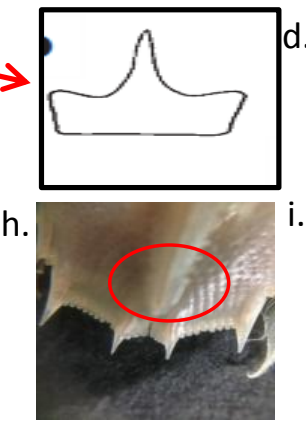

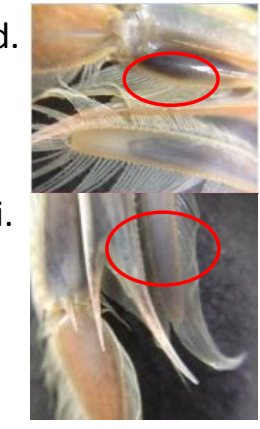

Gambar 2. Bagian-bagian Udang Mantis a) Intermediate denticles; b) Raptorial claw; c) Rostal plate; d) Uropod exsopod kehitaman; e) Median carina; f) exsopod bagian terminal; g) Telson; h) Submedian teeth; i) Uropod protopod dengan dua duri utama (Digital resource at www.catalogueoflife.org/col. Species 2000: Naturalis, Leiden, the Netherlands. ISSN 2405-8858)

Beberapa faktor yang diduga menjadi penyebab rendahnya keanekaragaman spesies Udang Mantis di ketiga stasiun tersebut salah satunya adalah daerah penangkapan. Berikut peta daerah penangkapan Udang Mantis di Perairan Kota Bengkulu.

Berdasarkan peta daerah penangkapan Udang Mantis berlokasi di sekitar perairan yang tidak jauh dari pantai (Gambar 3). Udang Mantis genus Harpiosquilla banyak dijumpai di perairan laut Indonesia. Satu diantara Udang Mantis dari genus Harpiosquilla yang banyak tertangkap para nelayan adalah jenis Harpiosquilla raphidea. Udang Mantis jenis ini merupakan target utama ekspor karena mudah didapatkan dan ukuran panjangnya dapat mencapai 38 cm (Manning 1969; Moosa 2000). Hasil penelitian ini juga sesuai dengan pernyataan Haswell (1982) dalam Sumiono dan Priyono (1998) bahwa Udang Mantis genera Harpiosquilla merupakan Udang Mantis yang paling banyak dijumpai di perairan laut Indonesia diantara 6 genera Udang Mantis yang tersebar di daerah IndoPasifik (Gambar 3).

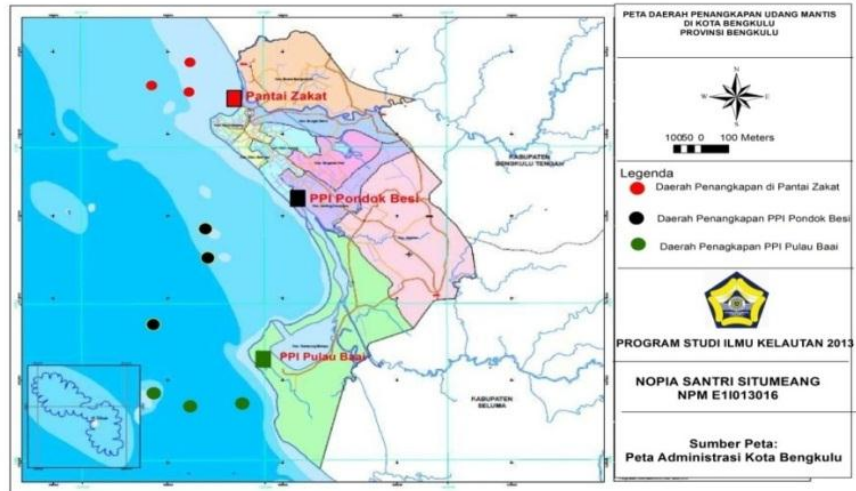

Gambar 3. Peta Daerah Penangkapan Udang Mantis di Kota Bengkulu (Google Earth, 2017) 
Penyebaran Udang Mantis di Indonesia hampir sama dengan penyebaran udang penaeid.Wilayah penyebaran Udang Mantis di Indonesia meliputi perairan Selat Malaka, pantai timur dan barat Sumatera, Laut Jawa, serta selatan Jawa (Sumiono dan Priyono, 1998). Halomoan (1999) melaporkan bahwa diperairan Teluk Banten ditemukan Udang Mantis jenis Squillahar paxde Haan; Azmarina (2007) melaporkan bahwa di perairan Bagansi api api ditemukan Udang Mantis jenis Harpiosquilla raphidea Fabricius; Ahyong dan Moosa (2004) dalam penelitiannya di Kepulauan Anambas, Natuna menemukan 12 spesies ordo Stomatopoda, diantaranya adalah Aerosquilla indica, Carinosquilla carinata, Oratosquilla perpensa, dan Oratosquilla quinquedentata; sedangkan di perairan Sulawesi Utara ditemukan spesies baru Udang Mantis, yaitu Lysiosquilloi desmapia (Barber and Erdman, 2002). Menurut Haswell (1982) dalam Damora (2010) Udang Mantis yang tersebar di daerah Indo-Pasifik terdiri dari enam genera, yaitu Squilla, Pseudosquilla, Lysiosquilla, Coronida, Odontodactylus, dan Gonodactylus.

Menurut Manning (1969), Harpiosquilla terdapat di Indo-Pasifik Barat mulai dari Jepang, Australia sampai ke Pasifik meliputi Laut Merha, Afrika Selatan, dan Samudera Hindia. Daerah penyebarannya meliputi Jepang (Teluk Suruga dan Teluk Tanabe), Taiwan (Tungkang), Queens land (Semenanjung Flattery danTeluk Tin Can), New South Wales (Teluk Jerusalem, Muara Sungai Hawk), Thailand (Tachalomdan Teluk Siam), Sri Langka (Teluk Palk), Madagaskar (Teluk Ambaro), Ethiopia (Teluk Arehico), Afrika Selatan (Teluk Richards), Laut Merah, danTeluk Oman, sedagkan di Indonesia terdapat di Laut Jawa sampai Singapura.

Pantai K ota Bengkulu merupakan pantai berpasir dan termasuk landai (RPJMD, 2013). Menurut Manning (1969) Harpiosquilla raphidea merupakan jenis udang yang hidup di daerah intertidal hingga subtidal dengan substrat lumpur atau lumpur berpasir. Berdasarkan hasil penelitian ini dapat diketahui bahwa Udang Mantis jenis $H$. raphidea mempunyai sebaran cukup luas, mulai dari daerah intertidal hingga daerah subtidal. Hal tersebut makin memperkuat hasil penelitian Manning (1969) dan Moosa $(1991 ; 2000)$ bahwa Udang Mantis (terutama genus Harpiosquilla) mempunyai sebaran cukup luas.

Faktor lain yang diduga berpengaruh terhadap rendahnya keanekaragaman spesies Udang Mantis yang diidentifikasi yaitu alat tangkap yang digunakan. Di Kota Bengkulu gillnet merupakan alat yang digunakan untuk menangkap Udang Mantis. Menurut Sadhori (1985), syarat-syarat daerah penangkapan yang baik untuk penangkapan salah satunya adalah dasar perairan tidak berkarang dan hal-hal yang perlu diperhatikan dalam penentuan daerah penangkapan diantaranya yaitu daerah perairan dengan dasar yang karang berpasir. Green (2008) menyatakan bahwa Udang Mantis hidup diantara terumbu karang yang sangat kompleks dan memiliki peran penting dalam ekosistem terumbu karang sebagai bioindikator dalam ekosistem laut, yaitu dengan menjaga populasi dan memelihara semua spesies yang ada baik secara langsung 
maupun tidak langsung. Pujawan (2012) perilaku hidup dari Udang Mantis yang menggali lubang pada terumbu karang memberi peluang untuk oksigenasi sehingga kesehatan terumbu karang akan lebih terjaga. Dari pernyataan tersebut diduga alat tangkap yang digunakan belum efektif untuk menangkap Udang Mantis.

Di Mukomuko Udang Mantis hanya dijadikan sebagai tangkapan sampingan (Rainaldi, 2016). Di Kota Bengkulu para nelayan juga menjadikannya sebagai tangkapan sampingan karena udang ini kurang diminati dikarenakan dagingnya yang sedikit dan baunya yang menyengat (amis). Namun demikian dari sumber lain mengatakan bahwa Udang Mantis merupakan salah satu komoditas hewan laut yang memiliki nilai ekonomi yang tinggi. Beberapa spesies Udang Mantis dikenal sebagai bahan makanan eksotis dan sebagai komoditas ekspor. Jenis-jenis Udang Mantis yang bernilai ekonomi dari spesies Harpiosquilla raphidea, Lysiosquillina maculata, Squilla empusa dan Squilla mantis (Moosa, 1997).

\section{KESIMPULAN DAN SARAN}

Berdasarkan penelitian dan identifikasi yang telah dilakukan dapat disimpulkan hanya terdapat 1 spesies Udang Mantis di perairan Kota Bengkulu yaitu Harpiosquilla raphidea dan daerah penangkapan berada di pesisir Pantai Kota Bengkulu. Penelitian ini merupakan penelitian awal untuk mendapatkan informasi tentang spesies Udang Mantis yang ada di Kota Bengkulu. Diperlukan adanya penelitian yang sama di daerah penangkapan Udang Mantis lainnya di Tepi Barat Sumatera khususnya di Perairan Laut Bengkulu.

\section{DAFTAR PUSTAKA}

Ahyong, S. T. and Moosa, M. K. 2004. Stomapod crustacean from Anambas and Natuna Islands, South a Sea, Indonesia. The Raffles Bulletin of Zoology. Supplement No. 11:61-66.

Ahyong , S.T., Chan, T.Y., dan Liao, Y.C., 2008. A catalogof the Mantis Shrimp (Stomatopoda) of Taiwan.

Azmarina, 2007. Karakteristik morfometrik Udang Mantis, Harpiosquilla raphidea (Fabricius 1798) di perairan Bagan Siapi-api [Skripsi]. Fakultas Perikanan dan IImu Kelautan, Universitas Riau. Pekan Baru.

Barber, P. H. and Erdmann, M. V. 2000. Molecular of the Gonodactylidae (Stomatopoda) using mitochondrial cytochromeoxidasec (subunit1) DNA sequencedata. J . Crust. Biol. AF205254.1 Gl:11078499.

Barber, P. H., Palumbi, S. R., Erdmann, M. V. and Moosa, M. K. 2002. 246 
Sharpgenetic break among populations of Haptosquilla pulshella (Stomatopoda) indicate limitto larval transport: patterns, causes, and consequences. Journal of Molecular Ecology 11, 659-674.

BDA. Bengkulu Dalam Angka. 2012. Kota Bengkulu. Bengkulu.

BPS. Badan Pusat Statistik Kota Bengkulu. 2012. Bengkulu Dalam Angka. Bengkulu.

Bliss. 1982. New stomatopod crustaceans from the Gulf of Tonkin, South China Sea. Crustaceana, 18 (2): 218-224.

Damora, A. 2010. Biologi Reproduksi Udang Mantis Harpiosquilla raphidea pada pantai berlumpur Kuala Tungkal, Kabupaten Tanjung Jabung Barat, Jambi [Skripsi]. Departemen Manajemen Sumberdaya Perairan, Fakultas Perikanan dan IImu Kelautan, Institut Pertanian Bogor. Bogor.

Green, A. 2008. Udang mini, species baru dari Halmahera. KOmpas.com.availablefromURL:

http//www.kompas.com/udangmantis.

Halomoan, M. 1999. Beberapa aspek biologi reproduksi udang ronggeng (Squillaharpax de Haan) di perairan Teluk Banten, Serang, Jawa Barat [Skripsi]. Departemen Manajemen Sumberdaya Perairan, Fakultas Perikanan dan IImu Kelautan, Institut Pertanian Bogor. Bogor.

Manning, R. B. 1969. A Review ogthegebus Harpiosquilla (Crustacea, Stomatoda), with descriptions of three new species. Smithsonian Contributions to Zoology Number 36. Smithsonian Institution Press. City of Washington.

Martin, J. W., dan Davis, G. E. 2001. An updated classification of the Recent Crustacea. Natural History Museum of Los Angeles County Science Series, 39:1-124.

Mashar, A. 2011. Distribusi spasial Udang Mantis Harpiosquilla raphidea dan Oratosquillina gravieri di Kuala Tungkal. Kabupaten Tanjung Jabung Barat Jambi [Skripsi]. Departemen Manajemen Sumberdaya Perairan, Fakultas Perikanan dan Ilmu Kelautan, Institut Pertanian Bogor. Bogor.

Moosa, M. 1997. Stomatopoda sebagai salah satu potensi sumberdaya hayati laut. Pewarta Oseana, 5:1-6.

Pujawan, A. G. N. O., Tjok, S. N., dan I Gusti, N. K. M. 2012. Identifikasi 
spesies Udang Mantis (Stematoda) di perairan Pemuteran dengan menggunakan gen cytochrome Coxidase subunit-1 dari DNA mitokondria. Indonesia Medicus Veterinus, 1(2): 268-280.

Rainaldi, B. 2016. Komposisi Hasil Tangkapan Sampingan (Bycatch) Perikanan Pukat Udang Skala Kecil Di Perairan Laut Pasar Bantal, Kabupaten Mukomuko. [Skripsi]. Fakultas Pertanian. Universitas Bengkulu. Bengkulu.

RPJMD. Rencana Pembangunan Jangka Menengah Daerah Kota Bengkulu. 2013 Kota Bengkulu. Bengkulu.

Sadhori, N. 1985. Teknik Penangkapan Ikan. Angkasa. Bandung. Bandung.

Septaria, E. 2013. Pemanfaatan Pelabuhan Pendaratan Ikan Bagi Kapal Penangkap/Pengangkutan Ikan Di Kota Bengkulu Berdasarkan Undang-Undang Perikanan. Tesis. Fakultas Hukum. Universitas Bengkulu. Bengkulu.

Sumiono, B. Dan Priyono, B. E. 1998. Potensi dan penyebaran sumberdaya ikan laut di perairan Indonesia. Komisi Nasional Pengkajian Stok Sumberdaya Ikan Laut dan P2O-LIPI. Jakarta.

Wardiatno, Y., Fajarallah, A., dan Mashar, A. 2009. Kajian aspek reproduksi dan genetika Udang Mantis (Harpiosquilla raphidea, Fabricius 1798) di Kuala Tungkal, Kabupaten Tanjung Jabung Barat, Jambi sebagai upaya lanjutan domestifikasi Udang Mantis. Institut Pertanian Bogor.Bogor. 